CONFUCIAN BIOETHICS 


\section{Philosophy and Medicine}

\section{VOLUME 61}

Editors

H. Tristram Engelhardt, Jr., Center for Medical Ethics and Health Policy, Baylor College of Medicine and Philosophy Department, Rice University, Houston, Texas

S. E Spicker, Massachusetts College of Pharmacy and Allied Health Sciences, Boston, Mass.

ASIAN STUDIES IN BIOETHICS AND THE PHILOSOPHY OF MEDICINE 1

Series Editor

Ruiping Fan, Center for Medical Ethics and Health Policy, Baylor College of Medicine, Houston, USA

Editorial Advisory Board

Kazumasa Hoshino, Kyoto Women’s University, Kyoto, Japan

Shui Chuen Lee, National Central University, Chung-li, Taiwan

Ping-cheung Lo, Hong Kong Baptist University, Kowloon, Hong Kong

Ren-Zong Qiu, Chinese Academy ofSocial Sciences, Beijing, China 


\title{
CONFUCIAN BIOETHICS
}

\author{
Edited by \\ RUIPING FAN \\ Centerfor Medical Ethics and Health Policy \\ Baylor College of Medicine \\ Houston, USA
}

\section{KLUWER ACADEMIC PUBLISHERS}

NEWYORK/BOSTON/DORDRECHT/LONDON/MOSCOW 
eBook ISBN: $\quad$ 0-306-46867-0

Print ISBN: $\quad$ 0-792-35723-X

(2002 Kluwer Academic Publishers

New York, Boston, Dordrecht, London, Moscow

All rights reserved

No part of this eBook may be reproduced or transmitted in any form or by any means, electronic, mechanical, recording, or otherwise, without written consent from the Publisher

Created in the United States of America

Visit Kluwer Online at:

http://www.kluweronline.com

and Kluwer's eBookstore at:

http://www.ebooks.kluweronline.com 


\section{TABLE OF CONTENTS}

RUIPING FAN / Introduction: Towards a Confucian Bioethics

PART I / BODY, HEALTH AND VIRTUE

PEIMIN NI / Confucian Virtues and Personal Health

ELLEN Y. ZHANG / The Neo-Confucian Concept ofBody and its

EthicalSensibility

PART II / SUICIDE, EUTHANASIA

AND MEDICAL FUTILITY

PING-CHEUNGLO/Confucian Views on Suicide and

Their Implications for Euthanasia

GEORGE KHUSHF / Reflections on the Dignity of Guan Zhong:

AComparison ofConfucian and Western Liberal Notions

of Suicide

EDWIN HUI/ A Confucian Ethic of Medical Futility

$$
\begin{gathered}
\text { PART III / "HUMAN DRUGS" } \\
\text { AND HUMAN EXPERIMENTATION }
\end{gathered}
$$

JING-BAO NIE / "Human Drugs" in Chinese Medicine and the

Confucian View: AnInterpretive Study

RONALD A. CARSON/Interpreting Strange Practices

XUNWUCHEN/A Confucian Reflection on Experimenting with

HumanSubjects

PART IV /JUST HEALTH CARE AND THE CONFUCIAN TRADITION

QINGJIE WANG / The Confucian Filial Obligation and Care for

Aged Parents

RUIPINGFAN / Just Health Care, the Good Life, and Confucianism 257

CHINESE GLOSSARY

NOTES ON CONTRIBUTORS

INDEX OF CHINESE TERMS

INDEX 